\title{
The Continuing Transformation of Labor and Working-Class History: A Review Essay
}

\author{
JOE W. TROTTER
}

Rick Halpern, Down on the Killing Floor: Black and White Workers in Chicago's Packinghouses, 1904-1954. Urbana and Chicago: University of Illinois Press, 1997. xiii, 309 pp. Notes, index. $\$ 44.95$ cloth, $\$ 17.95$ paper.

Roger Horowitz, "Negro and White, Unite and Fight!": A Social History of Industrial Unionism in Meatpacking, 1930-1990. Urbana and Chicago: University of Illinois Press, 1997. xvi, 376 pp. Illustrations, tables, notes, index. $\$ 44.95$ cloth, $\$ 17.95$ paper.

Rick Halpern and Roger Horowitz, Meatpackers: An Oral History of Black Packinghouse Workers and Their Struggle for Racial and Economic Equality. New York: Twayne Publishers, 1996. xvii, 177 pp. Illustrations, notes, appendixes, bibliography, index. $\$ 28.95$ cloth.

Shelton Stromquist and Marvin Bergman, eds., Unionizing the Jungles: Labor and Community in the Twentieth-Century Meatpacking Industry. Iowa City: University of Iowa Press, 1997. vi, 272 pp. Notes, index. $\$ 32.95$ cloth.

THE DEVELOPMENT of U.S. labor and working-class history is a tale of continuing transformation. The field had its roots in the struggle between capital and labor during the industrial era. Spearheaded by scholars such as John R. Commons, Selig Perlman, and Philip Taft, the so-called Wisconsin School of institutional economists established the intellectual foundations for the first wave of research on U.S. labor history. Closely aligned

THE ANNALS OF IOWA 57 (Winter 1999). (OThe State Historical Society of Iowa, 1999. 
with the movement to legitimize the ideas and social practices of organized labor in its confrontation with organized capital, the first generation of labor historians emphasized the doings of skilled trade unions and their leaders. Influenced by the new and more diverse social movements of the 1960s and 1970s, however, a growing number of scholars found the prevailing portrait of workers' lives wanting, particularly its privileging of skilled, formally organized, and predominantly American-born white and German and Irish immigrant workers.

Under the leadership of historians such as David Montgomery, David Brody, and Herbert Gutman, post-World War II scholars called for a new labor history that would acknowledge the role of African Americans as well as white immigrants from south, central, and eastern Europe. Partly because those groups were largely excluded from skilled jobs and thus also from trade unions and other labor organizations, the new labor history broadened its focus to include working-class cultures, families, and communities. At the same time, a burgeoning feminist movement pinpointed male biases in such studies and challenged historians to produce more gender-conscious labor and working-class history. By the early 1990s, studies by Alice Kessler-Harris, Patricia Cooper, and Elizabeth Faue, among others, accented gender as well as racial and ethnic inequality at work, at home, and in the larger community life of industrial America.

Together, the four books reviewed here reinforce the recent proliferation of research along multiple lines. Collectively, they tell the story of shifting social relations in the nation's stockyards and packinghouses along three interlocking fronts. They emphasize the transformation of the work process as capitalists initiated technological innovations; illuminate the ways technological changes and other managerial decisions and labor practices ushered in a more diverse but ethnically, racially, and sexually segmented and highly contentious labor force; and, most importantly, document the struggles of meatpacking workers to transcend segmentation, coalesce around common workplace issues, and create a grass-roots labor organization that would fight for the betterment of all workers. Those developments are described most forcefully and thoroughly in the monographs 
and oral history by Rick Halpern and Roger Horowitz, supplemented and extended by Shelton Stromquist and Marvin Bergman's edited collection of essays, Unionizing the Jungles.

RICK HALPERN'S STUDY of Chicago's rise to eminence in the meatpacking industry carefully and thoroughly assesses the transformation of the work process. Focusing on the business practices of Philip Armour, Nelson Morris, Gustavus Swift, and George Hammond-the so-called Big Four-Halpern documents the variety of mechanisms those industrialists used to gain control over the labor force. Industrialists dramatically increased the size of their operations and number of employees; creatively used all parts of the animal to produce marketable by-products, such as fertilizer and pharmaceuticals; and applied new technological innovations to make their operations more efficient. As Halpern shows, whereas the postbellum years opened with the skilled butcher or "knife-worker" at the center of the production process on the killing floors, "by the turn of the century the all-around butcher capable of performing the multitude of tasks involved in the slaughtering, cutting, and trimming operations had vanished. In his place were dozens of less-skilled men, each performing a single, repetitive task through the day" (17). Yet, unlike other industries such as auto and steel, the adoption of continuous flow or assembly-line methods left manual processes in place until the mid-1950s.

Roger Horowitz documents similar changes in the meatpacking industry in Chicago, Kansas City, Sioux City, and Austin, Minnesota. Unlike Halpern, however, Horowitz moves the focus forward to the mid-1950s through the late 1980s. He shows how the center of meatpacking moved out of the stockyards and multistory districts of these midwestern cities to dispersed and highly specialized rural and suburban locations. In addition, Horowitz documents the demise of the earlier Big Four meatpacking firms and the rise of new giants, the so-called Big Three: IBP, Excell (a subsidiary of Cargill), and ConAgra. He also details the technological changes that those producers ushered into the workplace. Moreover, the new packers further undercut the job of butchers by developing "boxed beef" operations, which mechanically cut and boned meat for the consumer 
market and sidestepped both the wholesaler and supermarket warehouses. Under the impact of these technological changes, Horowitz notes, the amount of meat produced by one hour of labor increased from 51 pounds in 1952 to 155 pounds in 1977 (253).

Horowitz and Halpern not only illustrate the ways capital succeeded in transforming the work process; they also illuminate the ways technological changes ushered in a more diverse labor force segmented by ethnicity, race, and gender. They show how a multiracial labor force supplanted an earlier white multiethnic one. Here, too, Rick Halpern's study opens up the earliest manifestations of that process. Against the back-drop of an already ethnically segmented labor force, in which German and Irish workers took the most secure skilled butcher jobs and Poles, Lithuanians, and other south, central, and eastern European workers took the bulk of low-paid "unskilled" or general labor jobs, Halpern carefully charts the racial conflicts that accompanied the initial entry of African Americans into the packinghouses as strikebreakers between the 1890 s and the onset of the Great Depression.

Halpern shows how different white ethnic groups gradually bridged the ethnic gap during that period and created their first national labor organization, the Amalgamated Meat Cutters and Butcher Workmen. Although new white immigrants also served as strikebreakers alongside blacks, white workers concentrated their attacks on black strikebreakers rather than whites, and helped to forge a white consciousness across ethnic and nationality lines. Blacks would serve as the glue holding the segmented white working class together. The predominantly skilled German and Irish labor movement gradually modified its ethnic and skill exclusivity and opened the door to the "house of labor" to the "unskilled" south, central, and eastern European workers. Thus, although blacks entered the industry in large numbers during the strikes of 1894 and 1904, both industrialists and white workers undercut the position of black workers in the strikes' aftermath.

The onset of World War I and its aftermath allowed African Americans to gain a firm foothold in the stockyards and packing plants. In Chicago, for example, they increased from 3 to 33 
percent of all packing workers. Chicago's meatpackers also came to include a growing number of women and Latino workers, who faced their own unique barriers in the workplace and larger community. As the number of black, Latino, and women workers increased in the wake of World War I, the predominantly male and skilled white labor movement made cautious overtures to the new workers. Unfortunately, as Halpern concludes, "Ultimately, these gains were undone and the movement destroyed, torn apart from within by internal factionalism and racial strife, and countered from without by the superior power of the packing companies" (45). Emboldened by the defeat of organized labor, large meatpacking firms introduced new welfare capitalist programs during the 1920s. Companybased unions, stock-sharing programs, pension plans, wage incentives and bonus schemes such as the Bedaux system, and a plethora of company-funded sports and leisure activities marked the spread of welfare capitalism.

Although packinghouse workers faced signal defeats in the post-World War I years, Halpern and Horowitz show how the rise of company unions and other forms of welfare capitalism nonetheless provided helpful forums for the development of organizational skills, group consciousness, and collective action. The labor movement of the 1930s, particularly the CIO, built on the interactions and capacities that workers developed during the repressive 1920s. Specifically, the CIO used existing workplace networks of workers to finally unite blacks and whites across the color line. The events of World War II reinforced that process, culminating in the formation of the United Packinghouse Workers of America (UPWA) in 1943. And, in the cold war era of the 1950s, the UPWA, unlike other CIO unions (notably, the United Steelworkers of America and the United Auto Workers), retained its militant grass-roots orientation and its alliance of black and white radicals, including members of the Communist Party. It also upheld the right of women to equal pay for equal work, and played a key role in the early postwar rise of the modern civil rights movement.

Still, the UPWA made certain accommodations under the conservative pressures of the cold war years. The organization eventually subdued its radical left wing by removing influential 
Communists from top national posts. The union also maintained significant racial barriers against the occupational mobility of black workers, and adhered to a fundamental gender division of labor. Women gained access to only a narrow range of jobs designated as female work. Moreover, Horowitz documents the effects of deindustrialization: the precipitous drop in black employment; the arrival of new workers, including large numbers of rural nonunion white men and single women, Latinos, and Southeast Asians; the decline of industrial unionism, symbolized by the bitter defeat of the Austin, Minnesota, Local P-9 in the Hormel strike of 1985-86; and the return of the drive system by the 1990s, as plants such as Morrell's in Sioux Falls increased the speed of the hog-killing line, with a resulting escalation of job injuries and days lost due to injuries.

Although Halpern and Horowitz offer the most detailed and systematic assessment of changing capital-labor relations in the meatpacking industry, Unionizing the Jungles makes its own unique contributions to the subject. The próduct of a lively and engaging conference sponsored by the Center for Recent United States History, Unionizing the Jungles includes a helpful discussion of the conference proceedings by the editors, Stromquist and Bergman, and illuminating, thoroughly researched, and carefully argued essays by Paul Street, Peter Rachleff, Wilson J. Warren, Bruce Fehn, Dennis A. Deslippe, Deborah Fink, and Mark A. Grey, in addition to contributions by Halpern and Horowitz.

In their larger works, both Horowitz and Halpern acknowledge the unique conditions at the plants of Swift and Company, the meatpacking industry's foremost practitioners of welfare capitalism, but Paul Street's essay in this volume offers a more detailed and sharply focused perspective on the transition of Swift's Chicago workers from a stance of "apparent company allegiance" to one of open commitment to industrial unionism. Similarly, in his analysis of Austin, Minnesota's Independent Union of All Workers, Peter Rachleff covers much of the same ground as Horowitz. Yet, unlike Horowitz, he concludes that the transition to the $\mathrm{CIO}$ weakened rather than empowered the union. As he puts it, "Under the pressure of external circumstances and hindered by internal conflicts, its leading activists 
opted for institutional security through national industrial unionism at the expense of the culture of local and regional solidarity that they, and the IUAW's rank and file, had built between 1933 and 1937" (69). Horowitz counters that Rachleff is vulnerable to the charge that "he neglects how the IUAW's regional focus reflected not only notions of working-class solidarity, but also parochial resistance to associating with workers of different race or ethnicity" (52). Focusing on the meatpacking communities of Omaha, Topeka, St. Joseph, and Ottumwa following the strike of 1948, Wilson Warren makes the same point. In his view, local ethnic and racial conflicts, particularly between blacks and whites, undercut the international's movement for social democracy (129). Nonetheless, as Bruce Fehn's essay on Waterloo Local 46 demonstrates, predominantly white locals "responded with varying degrees of enthusiasm and commitment to the UPWA's antidiscrimination program" (168). In the case of Local 46, black and white union activists waged spirited campaigns against racial discrimination against black women in the work force, as well as community-based discrimination in restaurants, theaters, motels, and hotels.

Dennis Deslippe and Deborah Fink offer the most telling assessments of new struggles around gender, immigration, and technological change. Focusing on the impact of Title VII of the Civil Rights Act of 1964 (which outlawed color and sex discrimination in employment), deindustrialization, and the relocation of industries to suburban and rural peripheral areas, Fink and Deslippe show how the interplay of government policy, economic crisis, and working-class feminism produced substantial opportunities for women workers, but failed to dislodge an entrenched pattern of gender inequality. Finally, Mark Grey illuminates the evolving and highly contingent nature of labor and capital relations in one community, Storm Lake, lowa, since IBP entered the town in 1982.

\section{DESPITE THEIR TREMENDOUS CONTRIBUTIONS to} knowledge, these studies nonetheless invite certain criticisms. Although both Halpern and Horowitz give substantial attention to the work process, for example, their treatment of so-called unskilled jobs from the perspective of black workers is uneven 
and less complete than it might have been, given their rich collection of oral interviews: Meatpackers: An Oral History of Black Packinghouse Workers. Their interviews conducted for the United Packinghouse Workers of America Oral History Project (sponsored by the State Historical Society of Wisconsin) offer extraordinary insight into the lives of black packinghouse workers. In one case, for example, an interviewee recalled, "Even if you were just a 16-year old kid shoveling shit out in the yards, you knew that you could get inside one of those plants, and then you could learn a skill and make some money" (28). In another instance, a black packinghouse worker articulated his view of the black workers' capabilities: "My brother was the hog splitter. $\mathrm{He}$ was an artist, could split those ribs. And I was the header of hogs. I was a fast butcher, very fast, and I wasn't the only one; there were others" (34). Words such as these invite us to probe more deeply into black workers' own perceptions of the relationship between dirty work, skills, and compensation.

Although Halpern and Horowitz link work place and community developments, their analysis of intraethnic and intraracial class relations are likewise uneven. Indeed, they offer significant discussions of developing class relationships within the black community, including black churches and social welfare and civil rights organizations such as the Urban League and the NAACP. Yet there is no corresponding analysis of class relations within the Polish, Lithuanian, Latino, and other ethnic communities. Moreover, these studies are conceptualized with varying degrees of sensitivity to existing scholarship on African American working-class and labor history. Halpern exhibits the keenest awareness of the overlapping scholarship on class and race. As such, he advances the discussion of race and class during the industrial era. Unfortunately, Halpern also downplays the class and labor (as opposed to race) contributions of scholars such as Dennis Dickerson, Earl Lewis, and Ronald Lewis, who, together, illuminate the varieties of African American workingclass experiences at different moments in time and in different regions of the nation.

Such critical commentary notwithstanding, these four books illuminate changing class, race, and gender relations in the meatpacking industry from the early post-Civil War years through 
the era of deindustrialization in recent times. They are based on a solid coterie of primary and secondary sources. In addition to a substantial body of published books and essays on the subject, these studies employ a plethora of newspaper accounts, manuscript collections, and oral interviews. While these studies reinforce the proliferation of research along multiple lines, they also give the project of synthesis a major boost. Collectively, they enable us to bridge gaps, illuminate the interconnectedness of the parts, and establish a sense of the whole. More importantly, however, these books and essays confirm the ongoing utility and necessity of specialized case studies. As such, they also highlight the contingent or provisional nature of any synthesis. 
Copyright of Annals of Iowa is the property of State of Iowa, by \& through the State Historical Society of Iowa and its content may not be copied or emailed to multiple sites or posted to a listserv without the copyright holder's express written permission. However, users may print, download, or email articles for individual use. 